\title{
Comparative Analysis of Croatian and Czech Lagging Regions
}

\author{
PhD Katarina Marošević, Associate Professor \\ Josip Juraj Strossmayer University in Osijek/Faculty of Law Osijek, Croatia \\ PhD Tomislav Sekur, Associate Professor \\ University in Zagreb/Faculty of Economics in Zagreb, Croatia
}

Doi: 10.19044/esj.2018.c4p5 URL:http://dx.doi.org/10.19044/esj.2018.c4p5

\begin{abstract}
Regional development is a central subject of different scientific areas of study, and especially economy since a region in a modern context represents a universal unit of monitoring (regional) development. Independent of the level of their development, national economies mostly bear the burden of regional inequalities and, grosso modo, of the existence of regions that fall behind in development. These regions are most vulnerable in post communist and highly centralized countries such as Croatia and the Czech Republic. Croatia and Czech Republic share many similarities, for example transitional post-communist background with centralized national economies dominated by capital city regions. Considering this, the aim of this paper is to analyse regions in Croatia with respect to their economic and social development with a detailed review of the least developed region. With that in mind, a comparative display of Czech Republic and issues concerning Czech lagging regions in economic and social development will be used to find the common denominator with similar problems in Croatian regions followed by suggestions for solutions on a regional level. This paper uses methods of description and comparative anaysis, wih an analytical review of data made available by relevant institutions.
\end{abstract}

Keywords: Regional development, lagging regions, decentralization, transition

\section{Introduction}

The common denominator of Croatia and Czech Republic is certainly their road through economic transition. Although beginnings of this process started more than two decades ago, its consequences are evident in specific economic indicators and problems. Some research, like Hartwell (2015) state that institutional frame connected to processes that precede transition is mostly 
treated either as an exogenous or a slow and gradual process. Kippenberg (2008) points out that different developments paths of specific countries in Central and Eastern Europe (CEES's) is mostly conditioned by different political decisions after 1989. In accordance with this, Harris (1996) states that period after 1989 is the time of substantial changes in Central and Eastern Europe, but also in other areas, for example ex-USSR countries. Assumption that transitional processes are followed and respected leads to the need to undergo decentralization and, as stated by Diaz-Serrano \& Rodriguez-Pose (2015), there is a lot of empiric research which connect decentralization to economic growth as well as establish a relation between decentralization and regional imbalances. The common feature of two selected economies is also connected to the process of accession to the European Union, although in different time period (Czech Republic: 2004; Croatia: 2013). Almost a decade after the Czech Republic Croatia became a full EU member as well, and a partial reason for this delay might be found in war and its consequences which required more than a few years to overcome. Due to strong initiatives for decentralization and economic integration national economies, in accordance with EU policies, mostly transition to smaller territorial units - regions. However, contrary to expectations as stated by Krieger-Boden, Morgenroth \& Petrakos (2008), integration of Eastern European countries in the EU resulted in an increase rather than decrease of regional differences. Since this paper focuses on examples of regional differences between Croatia and Czech Republic it is important to point out that, according to Balchin, Sykora \& Bull (1999), Czechoslovakia was the strongest proponent of equality policy in Central and Eastern European regions. The same authors, as stated by Blažek (1996), confirm that the introduction of free-market economy contributed to the increase in regional imbalances. On the other hand, Havrylyshyn, Meng \& Tupy (2016) claim that transition to free-market economy can create those differences with respect to different implementation policies. The argument between those that proposed quick or "big bang" reforms and those that advocated gradual approach and changes was settled in favor of fast reforms, which was evident in economic indicators (GDP) as well as social development indicators (Human Development Index). The existence of regional imbalances in Croatia is also a subject of a lot of research in specific contemporary published works (f.e. Đokić, Fröhlich \& Rašić Bakarić, 2015; Lončar \& Marinković, 2015, Tulumović, 2015). In the introductory part of this paper basic similarities between two national economies based on transition are clarified. Next chapter is reserved for a review of regional development in Croatia and Czech Republic, while the third chapter deals with analysis and comparison of chosen indicators which are important for measuring economic performance to show similarities and differences between two countries. The 
last part of this paper summarizes basic conclusions and puts forward some suggestions to promote a more balanced regional development in Croatia.

\section{Characteristics of regional development in Croatia and Czech Republic}

Similar historic circumstances on a transitional journey to change the economic system and introduce free-market economy, evident by reviewing chosen indicators, points to a lot of similarities in these processes in both countries. Furthermore, it is worth mentioning that regional imbalance which appeared is a common denominator in both cases. In this chapter individual aspects of development both in Croatia and Czech Republic will be shown. Kippenberg (2008) states that regional imbalances, and even regional economic divergence existed in Czech Republic from 1993 to 2003, and already in 1998 Czech government forms certain principles of regional policies to avoid regional divergence. However, the same author, according to Ich \& Larischova (1999) states that some of these measures have to be implemented due to integration in the EU, and not with the goal of reaching sustainable economic growth in Czech Republic. In a very similar situation in Croatia, Srića (2010) points out the effort to join the EU, and states that accession cannot solve national economic problems by itself. According to Kippenberg (2008) the presence of strong agglomeration of economic activities in the capital city of Czech Republic is evident as well as the increase in suburbanization in Stredocesky region. A part of population that left Prague found new homes in Stredocesky region based on supply of living space and housing close to the capital city but without the negative effects that are associated with it. The same applies to economic activities. Balchin, Sykora \& Bull (1999) point out that regional imbalances in Czech Republic also appeared due to growing unemployment in industrial regions and areas that are characterized by lagging behind, a more active development in western part of the country and selective concentration of foreign investments in Prague area, a few other selected major cities and western border zone. Dušek (2018) states that contemporary process of regional policy is directed to reduce imbalances in regional development and making sure that growth is balanced and sustainable and stresses the importance of cooperation between cities and municipalities in development of a specific area. Furthermore, the same author says that local initiatives become more and more important, and in certain circumstances become the most important factor in regional development. These, compared to regions smaller entities can influence the activation of local and regional resources and create a synergic effect. A similar opinion based on cooperation of regional institutions in public and private sector is shared by Stejskal, Kuvikova \& Meričkova (2018), who point out the importance of such cooperation with respect to promoting innovation-friendly environment which is the primary goal of regional innovation system. 
Croatia's regional policy reflects two approaches to regional (but also to general) development of Croatia. The first approach covers the period 19451991 and the main principles of regionalization, primarily gravitational principle, were respected. The main legacy of that period is the creation of four macro-regions with four major cities that should had the role of urban growth poles: Zagreb, Rijeka, Split and Osijek. The established macro-regions have been the basis, with slight changes, for all later regional divisions of Croatia until 1990. Respecting historical processes, principles of regionalization (homogeneity, gravity and functionality) and long-term economic interests, Croatia today is closest to division in four regions (Bogunović, 2011). The second approach covers the period 1991-present. During this period, the number of local units has skyrocketed by five times creating a bulky state apparatus with a very low degree of decentralization (in 2014, only $11 \%$ of the revenues and $10.5 \%$ of the expenditures were allocated at the local level) (Čavrak, Andabaka and Sekur, 2016). Furthermore, several legal acts and strategies have been adopted for fostering regional development. However, such a situation has created too many laws, directives and strategies with overlapping functions, which, in addition to the lack of political will to implement the reform of the regional and local structure, hampers equal regional development.

\section{Comparative review - Czech Republic vs. Croatia}

In the case of Croatia, for statistical purposes Eurostat - Regions in the European Union (2015) divided Croatian territory in three hierarchy NUTS levels: NUTS-1 level refers to Croatia itself, NUTS-2 level refers to Continental and Adriatic Croatia, and NUTS-3 level refers to 21 Croatian county, while the division of Czech Republic according to same source, for statistical purposes is made as following: NUTS-1 level refers to Czech Republic, NUTS-2 level refers to Praha, Střední Čechy, Jihozápad, Severozápad, Severovýchod, Jihovýchod, Střední Morava, Moravskoslezsko, and NUTS-3 level refers to 14 Czech counties. Furthermore, ratio of NUTS-2 and NUTS-3 regions in Croatia and Czech Republic reveals that NUTS-3 regions in Croatia are much smaller, but more numerous than in Czech Republic and most of Europe.

In this paper, we analyze and compare lagging regions of Czech Republic and Croatia on NUTS-3 level. One of the striking feature of Croatian regional state of affairs is pronounced economic and demographic strength of City of Zagreb relative to other parts of Croatia. For start, population of City of Zagreb accounts for $19.3 \%$ of Croatian population (Eurostat, 2018). If we add to this number a population of County of Zagreb, which highly gravitate to the City of Zagreb, this share climbs to $26.9 \%$ of Croatian total population living on a territory which compromises around $6.5 \%$ of total Croatian area 
(For comparison, 24.8\% of the Czech population live in Central Bohemian region which accounts for $14.6 \%$ of total Czech area). As far as the economic potential is concerned, the City of Zagreb (and its surroundings) account for $33.4 \%$ (39.3\%) of total Croatian GDP. City of Zagreb is also the richest region (measured with GDP p.c.) in Croatia - in 2015 its GDP p.c. was 19.100 EUR which is 3.4 times larger than the poorest region Virovitica-Podravina County (5.700 EUR) (Figure 1). For comparison, Prague (Hlavní mesto Praha) with 33.600 EUR p.c. in 2015 is 3.1 times richer then Czech's poorest NUTS 3 region - Karlovarský kraj 11.100 EUR p.c. Other Croatian counties that have GDP p.c. below 6.000 EUR are Brod-Posavina (5.800 EUR p.c.), PožegaSlavonia (5.900 EUR p.c.) and Vukovar-Sirmium (6.000 EUR p.c.). We can conclude by observing this parameter that Croatian lagging regions (as measured by GDP p.c.) are mainly situated in the eastern parts of the country. Figure 1 Gross domestic product p.c. at current market prices by NUTS 3 regions in EUR for Croatia and Czech Republic in 2015

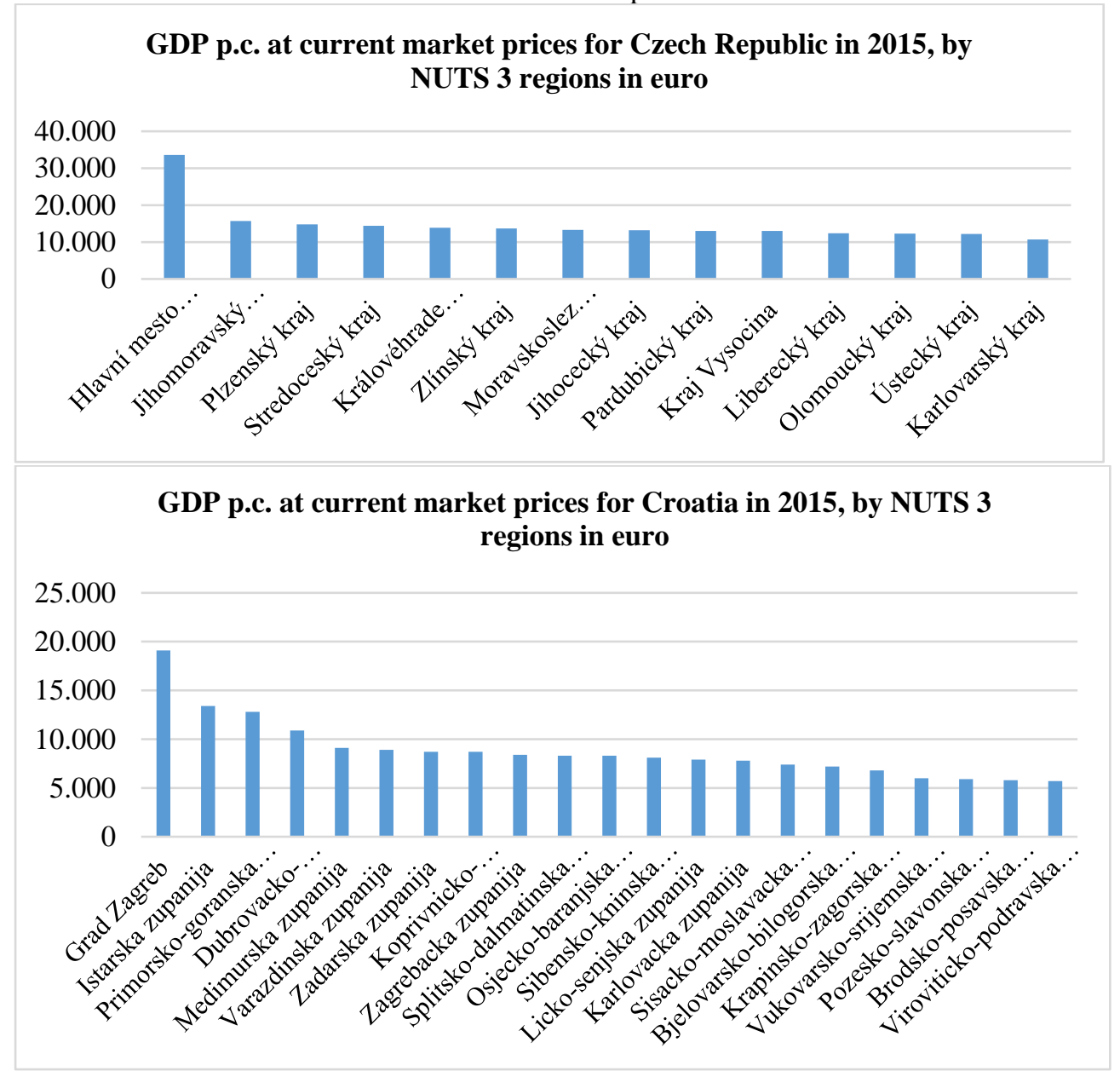

Source: Source: Own graphics: in accordance to Eurostat official page and Eurostat, 2018 
One of the major problems of Croatian economy and especially of the least developed regions is high rate of unemployment. According to Croatian Bureau of Statistics (2017), registered rate of unemployment of Croatia was $16.9 \%$ in 2016. Virovitica-Podravina County as Croatian poorest NUTS-3 region also had the highest rate of unemployment which was $32.7 \%$. Other NUTS-3 regions with the lowest GDP p.c. also had very high rates of unemployment, all above $20 \%$. Actually, there is high degree of correlation between GDP p.c. and the rate of unemployment (Figure 2).

Figure 2 Correlation between GDP p.c. and rate of unemployment for Croatian Counties in 2015

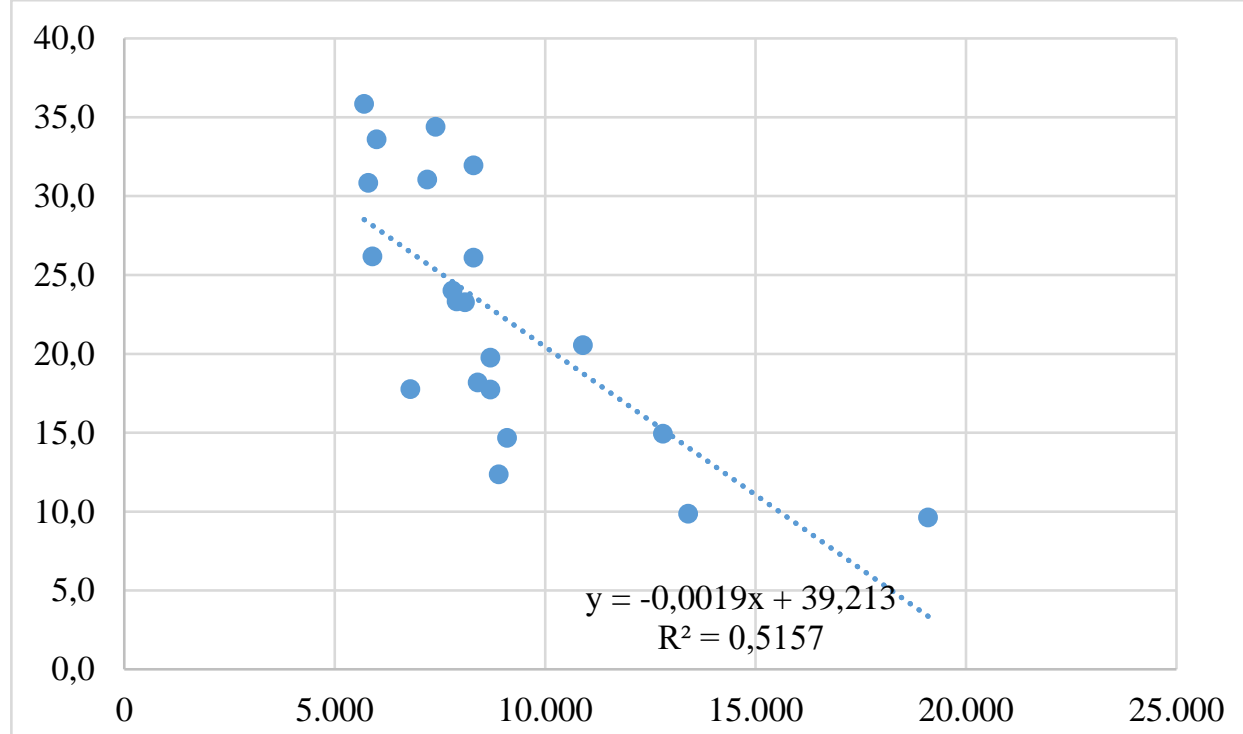

Source: Eurostat (2018), Croatian Bureau of Statistics (2017)

The same degree of correlation between GDP p.c. and the rate of unemployment is not evident in the case of Czech NUTS-3 regions. If we compare Croatian and Czech NUTS-3 regions, it is evident that Croatian regions are in worse position than Czech's in terms of either GDP p.c. or unemployment rate (Figure 3). City of Zagreb with the unemployment rate of 9.6\% in 2015 had the lowest rate in Croatia and yet that is higher than the Czech NUTS-3 region with the highest rate of unemployment in 2015 Ústecký kraj with the unemployment rate of $8.9 \%$ (Croatian Bureau of Statistics, 2017; Czech Statistical Office, 2018). 
Figure 3 Comparison of Croatian and Czech NUTS-3 regions by "GDP p.c. (thousands of EUR) - unemployment rate (\%)" correlation in 2015

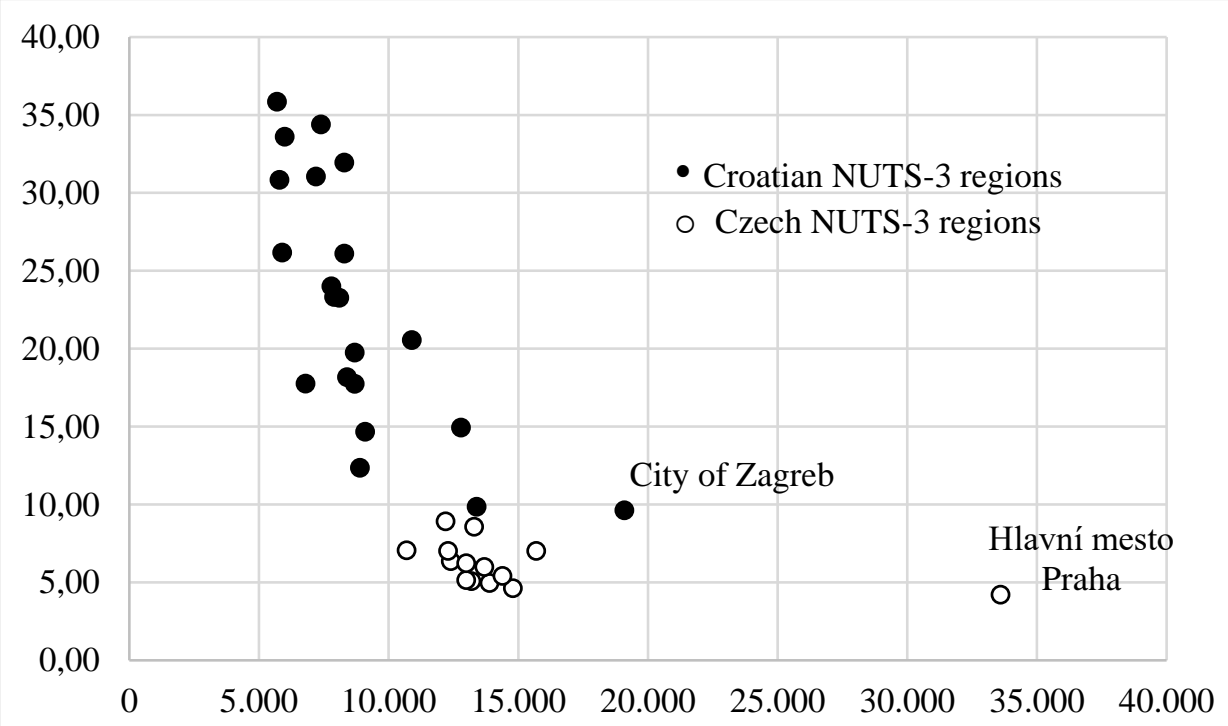

Source: Eurostat (2018), Croatian Bureau of Statistics (2017) and Czech Statistical Office (2018)

As shown on Figure 3, Czech NUTS-3 regions are more graphically concentrated (with the exception of Prague) suggesting lesser regional variations as measured by "GDP p.c.-unemployment rate" correlation On the other hand, Croatian NUTS-3 regions are more scattered and they occupy upper left part of the graph which implies lower GDP p.c., higher rates of unemployment and therefore greater regional inequalities than the Czech regions. It is indicative, as shown on Figure 3, that the problem of lagging regions is more pronounced in Croatia with the main difficulty being the enormously high unemployment rate in most of NUTS-3 regions. This may be the key reason for future Croatian demographic shrinkage and that will only worsen further development opportunities for lagging regions and Croatia in general.

The employment graph for certain parts of Czech Republic in 2015 is presented by the number of persons (thousands) and shows that Hlavní mesto Praha had the highest employment rate of all NUTS-3 regions, while at the same time Karlovarský kraj had the lowest employment rate. Regarding employment, situation in Croatia is almost identical if we observe asymmetry towards predominance of NUTS-3 region which also includes the city of Zagreb as the capital, while the lowest rate of employment was recorded in the NUTS-3 region of Lika-Senj county (Figure 4). 
Figure 4 Employment (thousand persons) in Czech Republic and Croatia by NUTS-3 regions in 2015

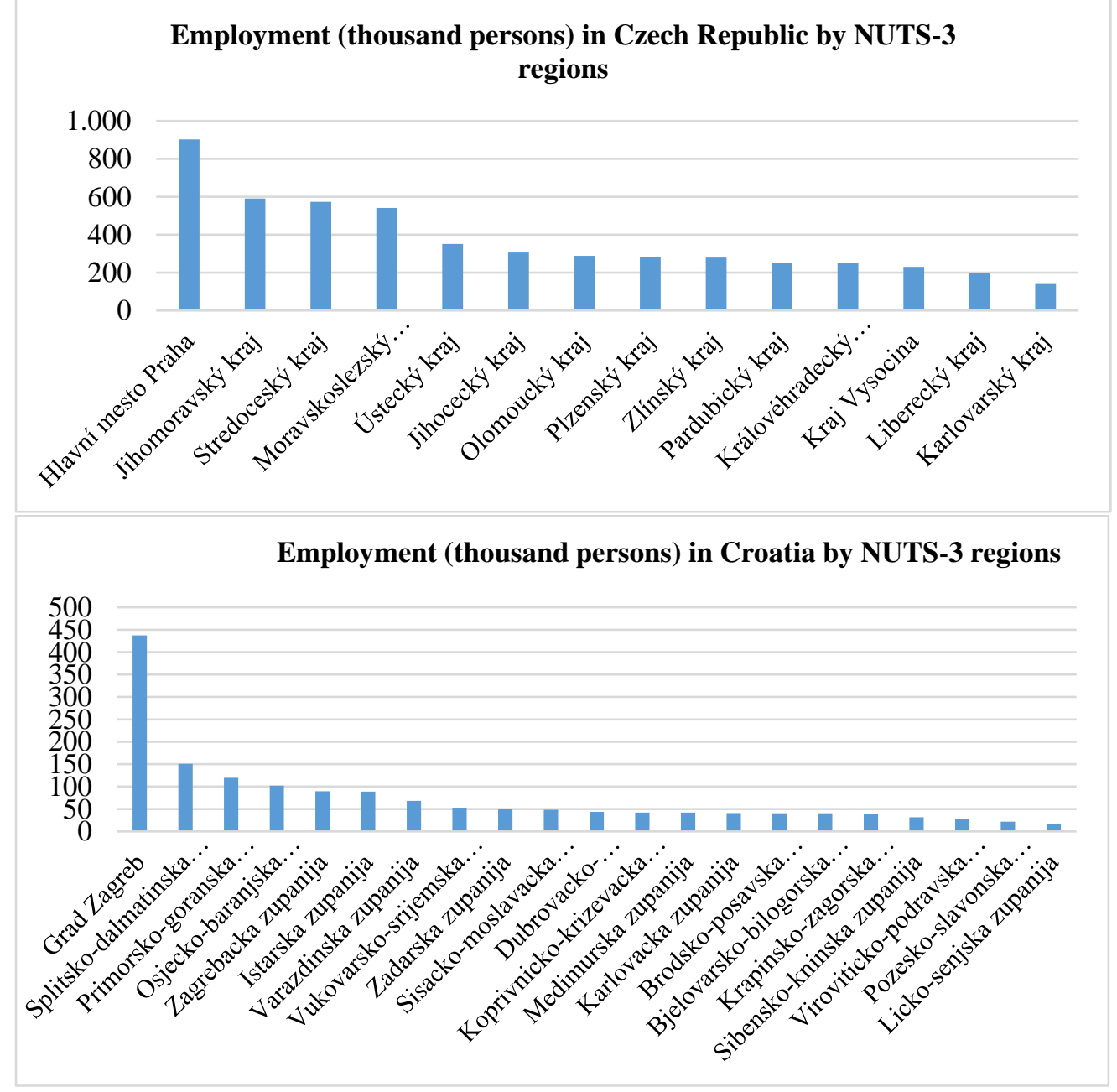

Source: Eurostat (2018)

Industry (more specifically manufacturing) is often regarded as a key factor in economic development especially for developing countries. One of the most important features of industry are its strong spillover effect to other sectors of the economy (e.g. mechanization of agriculture), generator of employment and its high share in exports (which is crucial macroeconomic variable for small open economies like Croatia and the Czech Republic). If we compare the share of manufacturing in GDP in 2015 (measured as the share of manufacturing in total Gross value added) of Croatia and the Czech Republic, we see great disproportion at national and regional level. Its share in Croatian GDP amounted 14.9\% whereas in the Czech's GDP it stood at 26.8\% (Eurostat, 2018). At the regional level, it is noticeable that Czech's 
regions have higher and more balanced shares of manufacturing in total Gross value added in their economies (Figure 5).

Figure 5 Share of manufacturing in total Gross value added in 2015 for Czech's and Croatian NUTS-3 regions

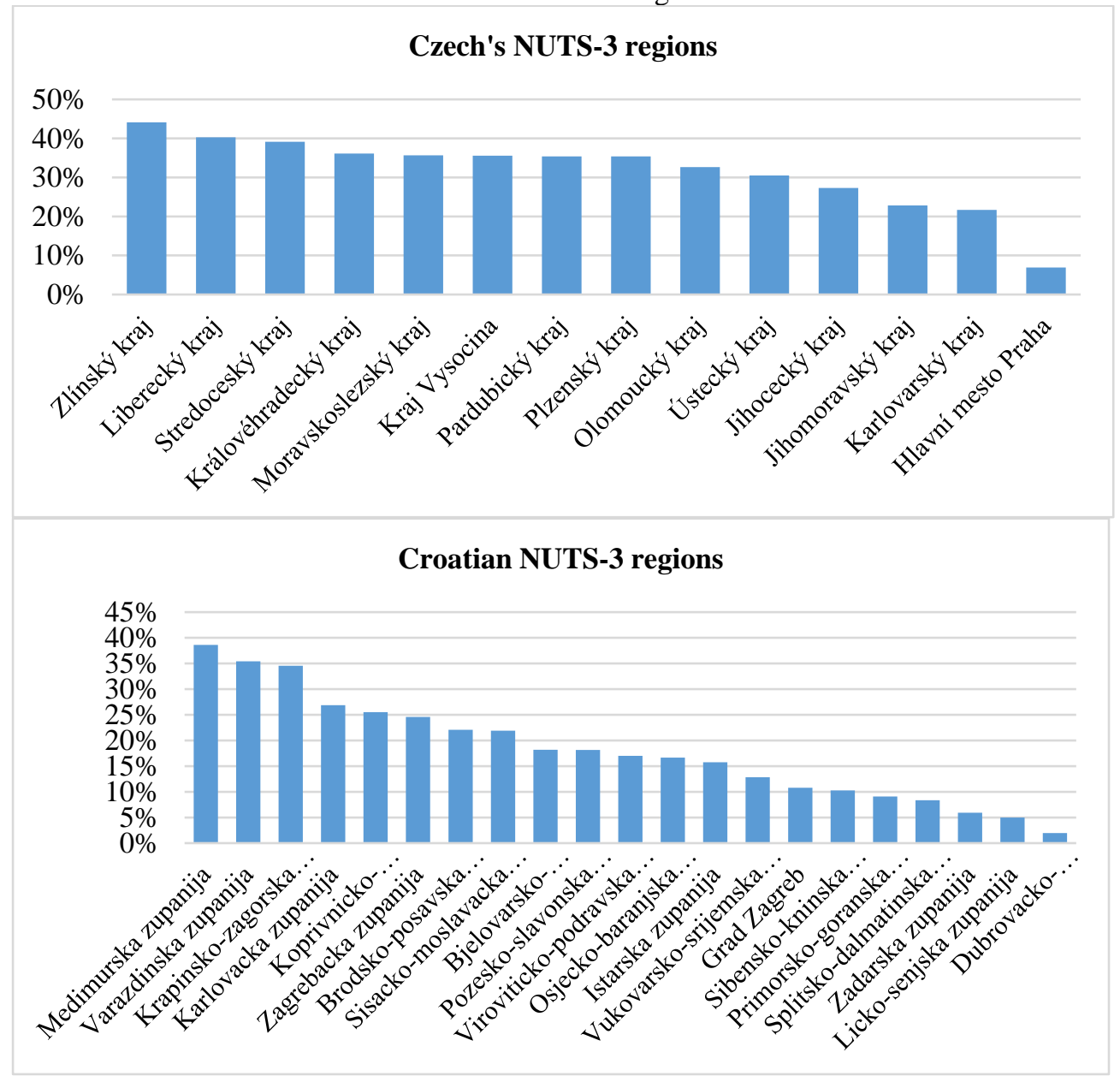

Source: Eurostat (2018)

Chosen indicators confirm theoretical foundations of this paper regarding intensive centralization that is present both in Czech Republic and in Croatia. There are numerous other indicators which would, sadly, also show the situation of extreme gaps between certain parts of national economies.

\section{Conclusive remarks and suggestions}

The confirmation of theoretical interpretation regarding predominance of one urban center in the selected national economies, those of Zagreb and Prague, is evident. The difference between the most and the least successful NUTS-3 regions is measured by the GDP p.c. is quite similar and sums up to 
a little over three times. The fact that the least developed Czech region (Karlovarsky kraj) had the similar level of GDP p.c. as some of the most developed Croatian NUTS-3 regions (Dubrovnik-Neretva County), is especially striking. The analysis also showed that the Czech regions (except for Prague) are much closer to each other in the sense of development level, while on the other hand the Croatian regions presented higher level of unequal development. From all of the above mentioned, we can conclude that regardless of choosing the different path while switching from one economy system to other, which is evident in the transitional process, Croatia and Czech Republic both had a quite similar choice of using the parts of economic policy which affect regional development. Putting more emphasis on the procedural character to getting close to the membership in the European Union, is one of the similarities. The future must necessarily change the existing economic differences. Some of the possibilities for improving this condition could be based on the cooperation of cities and counties regarding when developing a certain area and localization as the important tool which everyone with the adequate knowledge can use through activation of local and regional resources.

\section{References:}

1. Balchin, P., Sykora, L. \& Bull, G. (1999). Regional Policy and Planning in Europe, Routledge, London_New York.

2. Bogunović, A. (2011) Regionalna ekonomika i politika, Ekonomski fakultet, Zagreb.

3. Croatian Bureau of Statistics (2017). Statistika u nizu, Zaposlenost i plaće - pregled po županijama, Available at: https://www.dzs.hr/hrv/publication/StatisticsInLine.htm, (March 23 2018).

4. Czech Statistical Office (2018). Labour Statistics: Time Series of Basic Indicators - February 2018 [interactive], Available at: https://www.czso.cz/csu/czso/labour-statistics-time-series-of-basicindicators-february-2018, (April 4, 2018).

5. Čavrak, V., Andabaka, A., Sekur, T. (2016). Regionalni razvoj i fiskalna decentralizacija. In: Obadić, A. Tica, J. (eds) Gospodarstvo Hrvatske, Ekonomski fakultet Sveučilišta u Zagrebu, Zagreb, pp. 327366.

6. Diaz-Serrano, L. \& Rodríguez-Pose, A. (2015). Decentralization and the Welfare State: What Do Citizens Perceive? Social Indicators Research Vol 120, Is. 2, pp. 411-435.

7. Dušek J. (2018). How to Measure Intermunicipal Cooperation in Conditions of the Czech Republic. In: Dias A., Salmelin B., Pereira D., Dias M. (eds) Modeling Innovation Sustainability and Technologies. 
Springer Proceedings in Business and Economics. Springer, Cham, pp. 149-156. Available at: https://proxy.pravos.hr/cgi-bin/nphproxy.pl/hr/00/https/link.springer.com/chapter/10.1007/978-3-31967101-7_12, (March 23 2018)

8. Đokić, I., Fröhlich, Z. \& Rašić Bakarić, I. (2015). The impact of the economic crisis on regional disparities in Croatia, Cambridge Journal of Regions, Economy and Society

9. Eurostat, Regions in the European Union, Nomenclature of territorial units for statistics NUTS 2013/EU-28. Luxembourg. Available at: http://ec.europa.eu/eurostat/documents/3859598/6948381/KS-GQ14-006-EN-N.pdf/b9ba3339-b121-4775-9991-d88e807628e3, (April 2 2018)

10. Eurostat (2018). Eurostat database, Available at: http://ec.europa.eu/eurostat/data/database, (March 30, 2018).

11. Eurostat (2017) People in the EU - population projections, Available at: $\quad$ http://ec.europa.eu/eurostat/statisticsexplained/index.php/People_in_the_EU_\%E2\%80\%93_population_p rojections, (April 4, 2018).

12. Harris N. (1996). Central and Eastern Europe: economies in transition. In: European Business. Palgrave, London, pp. 115-155.

13. Hartwell, C. A. (2015). Institutional Reform: Irresistible Forces and Immovable Objects. In: Hölscher J., Tomann H. (eds) Palgrave Dictionary of Emerging Markets and Transition Economics. Palgrave Macmillan, London, pp. 153-169.

14. Havrylyshyn, O., Meng, X. \& Tupy, M. (2016). 25 Years of Reforms in Ex-Communist Countries: Fast and Extensive Reforms Led to Higher Growth and More Political Freedom, Cato Institute Policy Analysis No. 795, Available at SSRN: https://papers.ssrn.com/sol3/papers.cfm?abstract_id=2833941, (28 February 2018).

15. Kippenberg, E. (2008). Regional economic divergence patterns in the Czech Republic. In: Krieger-Boden, C., Morgenroth, E. \& Petrakos, G. (ed). The Impact of European Integration on Regional Structural Change and Cohesion, Oxon-New York: Routledge, str. 197-221.

16. Krieger-Boden, C., Morgenroth, E. \& Petrakos, G. (2008). The Impact of European Integration on Regional Structural Change and Cohesion, Oxon-New York: Routledge, Introduction.

17. Lončar, J., Marinković, V. (2015). Analysis of socio-economic indicators in the context of the regional development of Eastern Croatia, Hungarian Geographical Bulletin 642015 (4) pp. 327-344. Available at: http://realj.mtak.hu/6399/4/HunGeoBull_64_4.pdf\#page=67, (April 1 2018) 
18. Srića, V. (2010). Hrvatska 2020, Profil International, Zagreb

19. Stejskal J., Kuvíková H., Meričková B.M. (2018). Regional Innovation Systems Analysis and Evaluation: The Case of the Czech Republic. In: Stejskal J., Hajek P., Hudec O. (eds) Knowledge Spillovers in Regional Innovation Systems. Advances in Spatial Science (The Regional Science Series). Springer, Cham, pp. pp 81-113.

20. Tulumović, V. (2015). Models of regional aspect and development underdeveloped regions, Journal of International Social Research Vol 8, Is. 40 , pp. $806-814$ 